REVISTA de

PEDAGOGIE
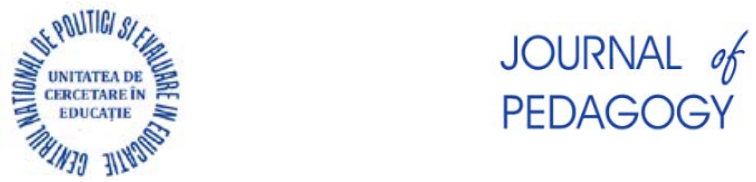

http://revped.ise.ro

Print ISSN 0034-8678; Online ISSN: 2559 - 639X

\title{
LEARNING FROM PISA EXPERIENCES: READING TASKS TO EXPLORE BIASED INFORMATION
}

Învățând din experiențele PISA: antrenamente de lectură pentru explorarea informațiilor părtinitoare

\section{Angelica MIHĂILESCU, Ligia SARIVAN}

Journal of Pedagogy, 2020 (2), 165 - 180

https://doi.org/10.26755/RevPed/2020.2/165

The online version of this article can be found at: http://revped.ise.ro/en/2020/

\section{(ㅇ) $\odot \odot$}

This work is licensed under the Creative Commons Attribution-NonCommercial-ShareAlike 4.0 International License.

To view a copy of this license, visit http://creativecommons.org/licenses/by-nc-sa/4.0/ or send a letter to Creative Commons, PO Box 1866, Mountain View, CA 94042, USA.

Published by:

Centrul Național de Politici Și Evaluare în Educație

UNiTATEA DE CERCETARE ÎN EDUCAȚIE

http://www.ise.ro/

https://rocnee.eu/

Further information about Revista de Pedagogie - Journal of Pedagogy can be found at:

Editorial Policy: http://revped.ise.ro/editorial-policy/

Author Guidelines: http://revped.ise.ro/en/author-guidelines/ 


\section{ÎNVĂ ÂND DIN EXPERIEN ELE PISA: ANTRENAMENTE DE LECTURĂ PENTRU EXPLORAREA INFORMA IILOR PĂRTINITOARE}

\section{Angelica Mihăilescu* Ligia Sarivan**}

Centrul Na ional de Politici şi Evaluare în Educa ie, Unitatea de Cercetare în Educa ie,

București, România

angelica.mihailescu@ise.ro,ligia.c.sarivan@gmail.com

\section{Rezumat}

Lucrarea prezintă rezultatele unui studiu la care au participat, în septembrie 2020, 70 de elevi din clasa a IX-a, din două licee cu profil tehnologic, situate într-un oraş mare din România. Tinerii de 15 ani au citit şi au răspuns la întrebările din cadrul uneia dintre unită ile publicate după PISA 2018. De asemenea, ei au reflectat asupra experien ei lor de lectură într-o fişă de autoevaluare. Rezultatele arată performan e bune în lucrul cu informa iile provenite dintr-un articol şi capacitatea slabă de a corobora informa ii contradictorii din două surse care vizează acelaşi subiect. Elevii dovedesc pu ină familiaritate cu informa iile părtinitoare, chiar dacă majoritatea s-a bucurat de provocarea de lectură a două puncte de vedere divergente. Rezultatele sunt în concordan ă cu trendul de lectură PISA pentru România. Pentru a îmbunătă i comprehensiunea de text, este nevoie de o înnoire a practicilor de lectură prin implicarea elevilor în citirea multor texte şi în rezolvarea de sarcini care se concentrează pe evaluare şi reflec ie şi pe credibilitatea surselor.

Cuvinte-cheie: comprehensiunea textului, informa ii părtinitoare, PISA, practici de lectură.

* Cercetător ştiin ific dr., Centrul Na ional de Politici şi Evaluare în Educa ie, Unitatea de Cercetare în Educa ie, Bucureşti, România.

** Cercetător ştiin ific dr., Centrul Na ional de Politici şi Evaluare în Educa ie, Unitatea de Cercetare în Educa ie, Bucureşti, România. 


\section{Abstract}

The paper presents the results from a study involving 70 students in grade 9, from two technological highschools situated in a large town in Romania. In September 2020, the 15 year olds read and answered the questions from one of the released units after PISA 2018, and then reflected on their reading experience in a self assessment sheet. The results show good results in working with information from one article and poor ability in corroborating conflicting information from two sources that focus on a same topic. The students display little familiarity with biased information even if the majority enjoyed the reading challenge of two divergent points of view. The results are consistent with the PISA reading trend for Romania. In order to improve reading comprehension, teachers should renovate the reading practices by challenging students with work on multiple texts and tasks that focus on evaluation and reflection and on the sources credibility.

Keywords: biased information, PISA, reading comprehension, reading practices.

Rezultatele mediocre ale elevilor români la studiile interna ionale sunt cunoscute de actorii şcolii şi de către publicul larg. Ele atrag adesea reac ii amestecate - de la negarea eviden elor la teoria conspira iei şi la blamarea lipsurilor materiale sau a slăbiciunilor şcolii. Dincolo de ierarhia mediilor înregistrate, chestiunea cu adevărat importantă rămâne însă aceea de a-i sprijini pe elevi să ajungă la învă are de calitate, relevantă pentru via ă, pentru integrarea socială şi pe pia a muncii (Sarivan, Novak, Mihăilescu \& Pleşa, 2020). 


\section{Contextul şi justificarea cercetării}

Analiza pe care o prezentăm îşi propune să ofere repere pentru renovarea şi inovarea practicilor de lectură din perspectiva modului în care elevii explorează textele care includ informa ii părtinitoare. Cu precădere în contextul actual, în care fenomenul „fake news” are o amploare endemică, identificarea surselor părtinitoare devine relevantă pentru o raportare coerentă la lumea în care trăim; iar elevii trebuie să fie pregăti i, în şcoală, să facă fa ă unor astfel de provocări de lectură. Din această perspectivă, itemii publici PISA constituie un punct de plecare valoros. Men ionăm că în Cadrul de referin $\breve{a}$ PISA lectura reprezintă ,în elegerea, utilizarea, evaluarea, reflectarea şi interac iunea cu textele în vederea atingerii scopurilor, a dezvoltării orizontului de cunoaştere şi a propriului poten ial, precum şi în vederea participării la via a socială" (OECD, 2019a, p. 28). Se observă că această defini ie aduce în actualitate lectura, prin distan are fa ă de abordarea canonică şi prin angajarea subiectului cititor într-o aventură cognitivă cu relevan ă personală şi socială. În cadrul PISA, lectura eficientă implică activarea mai multor procese care sunt clasificate în trei mari categorii: localizare, în elegere, evaluare-reflec ie (OECD, 2019a, pp. 33-38).

În studiul de fa ă, propunem o analiză a răspunsurilor unui lot de 70 de elevi de 15 ani la o serie de solicitări de lectură din testele PISA incluse în categoria „evaluare-reflec ie”, vizând cu precădere procesul de detectare şi rezolvare a conflictelor. În mod specific, întrebările din această categorie îi cer elevului să determine dacă textele multiple pot fi coroborate sau se contrazic şi să rezolve conflictul în cazul în care apare unul. Itemii care vizează acest proces solicită identificarea pozi iilor, eventual diferite, eventual părtinitoare, ale unor autori fa ă de o problemă sau explorarea credibilită ii surselor, inclusiv demonstrarea că o sursă este mai de încredere decât altele descoperite/ avute la dispozi ie (ibidem).

\section{Metodologia cercetării}

Analiza a fost orientată de următoarea întrebare: Cum operează elevii cu texte care oferă puncte de vedere diferite asupra unei problematici? Elevilor din trei clase a IX-a, liceu tehnologic, dintr-un oraş mare, li s-a 
propus spre rezolvare o unitate de lectură care face parte din antologia itemilor publica i de OECD după evaluarea din 2018 (OECD, 2019b). În evaluarea răspunsurilor elevilor la întrebările din unitate s-a utilizat ghidul de codificare publicat de aceeaşi sursă. Elevii au completat şi o fişă de autoevaluare, cuprinzând opt întrebări, dintre care patru au presupus un răspuns deschis. Întrebările au vizat aspecte privind modul în care elevii sau raportat la experien a rezolvării unită ii: aprecierea gradului de dificultate privind textul şi sarcinile; gradul de satisfac ie privind activitatea de rezolvare a sarcinii; experien e prealabile privind în elegerea textului care exprimă mai multe puncte de vedere; strategii de recunoaştere/în elegere a unui text părtinitor. În context mai larg, a fost urmărit gradul de interes fa ă de lectură.

\section{Rezultate}

3.1. Care sunt rezultatele ob inute de elevi la unitatea de lectură „Laptele de vacă”?

Unitatea parcursă de elevi, „Laptele de vacă”, propune un scenariu care contextualizează lectura: trei tineri observă un afiş, într-o cafenea, care anun ă că nu se mai serveşte lapte de vacă, ci un substitut pe bază de soia. Tinerii devin curioşi şi îşi folosesc telefoanele pentru a căuta informa ii referitoare la laptele de vacă, apoi discută rezultatele.

Textul unită ii este multiplu, cuprinzând două pagini de internet. Prima apar ine unei firme de produse lactate, iar cea de-a doua, unui site de sănătate care include un articol cu titlul ,Spune NU laptelui de vacă” (vezi figura nr. 1; http://www.ise.ro/itemi-pisa). 

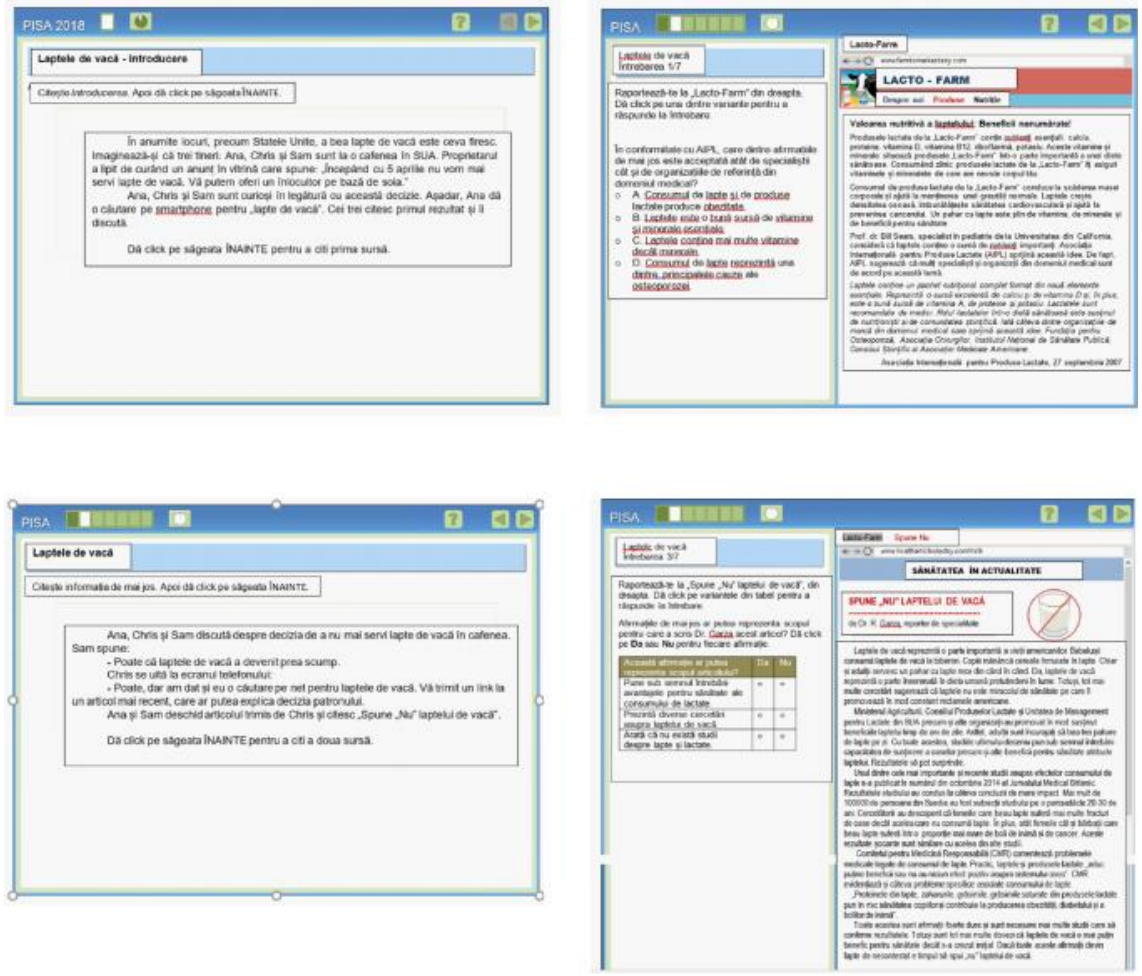

Figura nr. 1. Provocări de lectură: Elevii citesc ecrane în cadrul unită ii „Laptele de vacă”

La început, elevul citeşte pagina producătorului de lactate şi rezolvă sarcinile aferente con inutului articolului. După o actualizare a scenariului, care indică o a doua pagină de internet, elevul citeşte articolul de pe site-ul de sănătate şi răspunde la întrebări, pe marginea acestuia. În cele din urmă, este solicitată coroborarea informa iilor din cele două surse. Motiva ia acestei etapizări este următoarea: „Acest tip de abordare îi permite elevului să-şi demonstreze performan ele în cazul întrebărilor care se raportează la un singur text şi, apoi, abilită ile de a opera cu informa ii din mai multe texte. Această modalitate de dezvoltare a testului este foarte importantă pentru că există cititori care procesează informa ia când este prezentată într-un singur text, chiar şi atunci când trebuie să integreze informa ii la nivelul respectivului text, dar care au 
probleme când trebuie să integreze informa ii din mai multe texte. Acest design de test le permite elevilor cu niveluri diferite de abilitate să-şi demonstreze performan ele, măcar pentru unele sec iuni ale unită ii”' (OECD, 2019b, p. 18).

Rezultatele ob inute de cei 70 de elevi la cele 7 întrebări de lectură din cadrul unită ii ,Laptele de vacă” sunt sintetizate în graficul de mai jos. Barele portocalii reprezintă răspunsuri adecvate, cele albastre, răspunsuri neadecvate, iar cele gri reflectă absen a răspunsului.

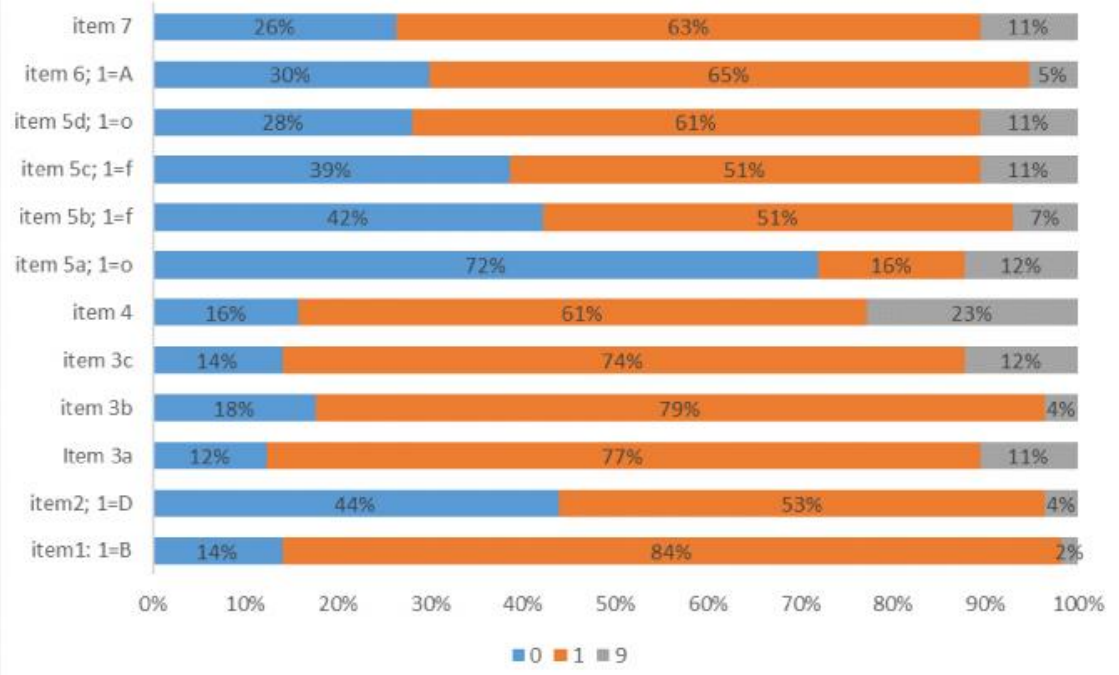

Figura nr. 2. Rezultatele ob inute de elevi la întrebările de lectură din unitatea „Laptele de vacă”

Performan ele cele mai bune s-au înregistrat la întrebările 1 şi 3 a, b, c, respectiv, în cazurile în care elevii s-au raportat la un singur articol. A doua jumătate a unită ii, când solicitările au vizat coroborarea informa iilor din cele două articole şi rezolvarea conflictului cognitiv rezultat din punctele de vedere diferite, a pus probleme cititorilor. $\mathrm{Cu}$ precădere, întrebarea 5a s-a dovedit a avea un grad mare de dificultate pentru elevii participan i. 


\section{În mod concret:}

- Elevii ob in cele mai bune rezultate la întrebarea 1. Aceasta este catalogată ca având un grad minim de dificultate (solicită o parafrază a unui citat din articol); este cu alegere multiplă; vizează procesul de reprezentare literală.

- Rezultate bune se ob in şi la întrebarea 3. Aceasta con ine trei afirma ii pentru care elevul trebuie să stabilească valoarea de adevăr, în raport cu informa iile din text (prin completarea într-un tabel cu DA/NU). Întrebarea se referă la în elegerea scopului pentru care autorul a scris articolul (de pe pagina de sănătate). Procesul vizat este de reflectare asupra con inutului şi a formei. Nivelul de dificultate este moderat (3). Men ionăm că în cadrul PISA, sunt 6 niveluri de dificultate.

- La polul opus, cea mai grea întrebare s-a dovedit a fi 5. Aceasta solicită recunoaşterea unor fapte sau opinii din text, prin bifarea într-un tabel F/O. Procesul vizat se referă la generarea inferen elor. Gradul de dificultate este ridicat (5). Cea mai problematică afirma ie a fost prima: „Studiile recente vizând beneficiile consumului de lapte sunt surprinzătoare". Cei mai mul i elevi nu au recunoscut că aceasta reprezintă opinia autorului, ci au considerat-o un fapt prezentat în articol. O asemenea confuzie conduce la reprezentarea greşită care presupune preluarea mesajului textului ca şi când ar avea valoare de adevăr.

- Întrebările 6 şi 7 sunt relativ dificile pentru elevi. Nr. 6 solicită identificarea dezacordului dintre cei doi autori, pe bază de alegere multiplă. Nr. 7 este o întrebare cu răspuns construit: elevul trebuie să explice cu care dintre cei trei tineri, Ana, Chris sau Sam, este de acord (cei trei tineri îşi exprimă, fiecare, punctul de vedere în legătură cu consumul de lapte).

- Întrebarea 2, deşi se referă la informa iile dintr-un singur articol, deşi se prezintă, ca şi întrebarea 1, sub formă de alegere multiplă, deşi are un nivel de dificultate relativ scăzut (2), pune totuşi probleme elevilor, conducând la performan e similare celor de la finalul unită ii (respectiv, pentru acele întrebări care solicită coroborarea informa iilor contrastante din două articole). O posibilă explica ie a acestei situa ii îşi află originea în descrierea făcută în antologia PISA: ,În cadrul acestui item, elevul trebuie să identifice scopul principal al paginii. Aten ie! Nu se solicită identificarea ideii principale. Elevul va trebui să în eleagă semnifica ia globală a textului şi apoi să aprecieze de ce i se prezintă pagina web respectivă şi cum este redactată aceasta. Elevul trebuie să reflecteze asupra con inutului şi a formei textului” (OECD, 2019b, p. 20). De aici, 
putem face presupunerea că o anumită rutină de extragere a ideilor principale interferează cu solicitarea din întrebarea 2 şi îi trimite pe elevi pe o falsă pistă de reprezentare cognitivă.

Majoritatea întrebărilor din unitatea „Laptele de vacă” sunt fie cu alegere multiplă, fie de tip adevărat/fals (cu varia iuni: Fapt/Opinie, Da/Nu). Observăm că nu forma itemului face diferen a, ci natura procesului de lectură implicat. Totodată, putem afirma că dificultatea apare şi în cazul ciocnirii dintre sarcina specifică de lectură şi o practică de lectură care îl vulnerabilizează pe cititor: acesta ,citeşte” ceea ce crede că se cere, în virtutea obişnuin ei de a realiza un anume demers (a se vedea mai sus dificultatea pe care am presupus-o că ar fi derivată din obiceiul de a extrage idei principale).

3.2. Cum au reflectat elevii asupra experien ei de lucru cu unitatea de lectură „Laptele de vacă”?

La încheierea sesiunii de rezolvare a sarcinilor de lucru din unitatea „Laptele de vacă", elevii participan i la studiu au completat un chestionar, care a vizat experien a de lucru a acestora, prin intermediul a 4 întrebări închise şi 4 cu răspuns deschis.

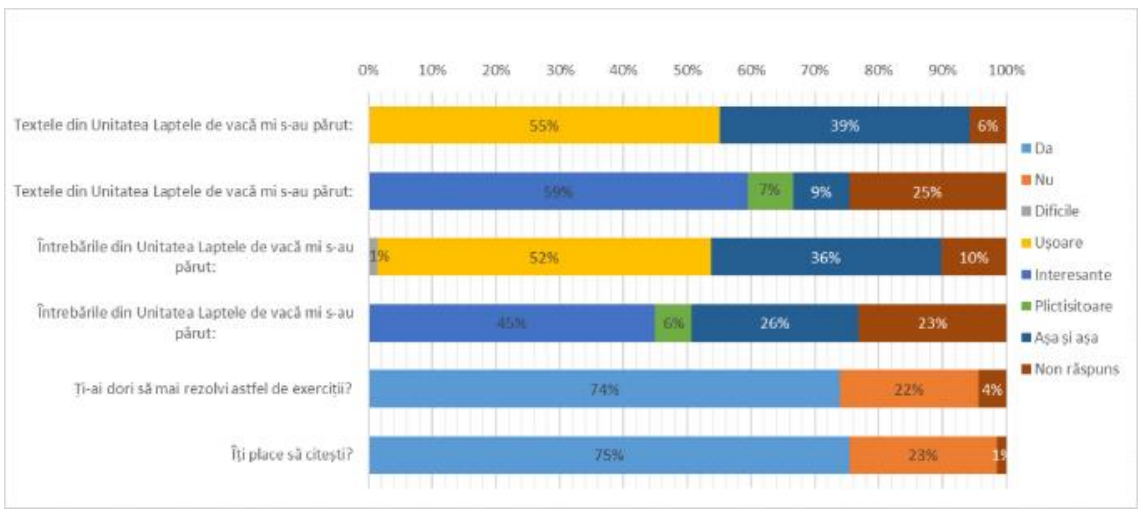

Figura nr. 3. Opiniile elevilor cu privire la experien a de lucru cu unitatea „Laptele de vacă” 
Reflec ia asupra propriei experien e de lucru a fost vizată prin întrebările 1 şi 2 din chestionar, focalizate pe identificarea modului în care elevii au perceput textul şi exerci iile din unitatea de testare. Pentru formularea unor aprecieri, elevii au avut la dispozi ie două serii de calificative: a. dificil (D)/ uşor (U)/ aşa şi aşa (A); b. interesant (I)/plictisitor (P)/aşa şi aşa (A). După cum se poate observa din figura de mai sus, rezultatele relevă faptul că atât textele cât şi sarcinile din unitatea „Laptele de vacă” au fost apreciate de elevi ca fiind interesante şi uşoare sau medii, ca solicitare. Gradul de dificultate resim it de elevii care au ales să ofere un răspuns este foarte mic. Se observă un procent de aproape un sfert dintre responden i care nu şi-au exprimat opinia pentru seria a doua de calificative. Faptul că în acest caz numărul ocuren elor de nonrăspuns este mult mai mare poate indica o citire superficială.

În genere, unitatea „Laptele de vacă” a fost percepută de majoritatea elevilor ca fiind accesibilă, interesantă, ca text şi sarcini/exerci ii. O treime dintre responden i apreciază că exerci iile au fost plăcute pentru că au fost simple, interesante, creative, distractive şi educative. Atât sarcinile, cât şi textul, „sursa”, au fost atractive deoarece ,am mai aflat ceva nou”; ,mi-a plăcut, deoarece sursele au fost interesante".

Aproape to i elevii participan i la studiu şi-au exprimat opinia în legătură cu modul în care au perceput această experien ă de lucru (întrebarea 4: i-a plăcut să rezolvi exerci iile din această unitate?) şi au furnizat o explica ie. Accesibilitatea sarcinilor a fost marcată prin frecven a mare a opiniilor care relevă confortul responden ilor în raport cu sarcina: ,plăcut”; ,,au fost simple”; ,interesante"; ,pu in dificile”; , uşoare”; ,mi-au plăcut itemii”. De asemenea, răspunsurile elevilor relevă afinitate fa ă de acest gen de probă, insitând pe atractivitatea întrebărilor şi a subiectului abordat: ,Sursele au fost interesante”; „Mi-a plăcut să rezolv exerci iile, pentru că au fost interesante şi, în plus, că am mai aflat ceva nou"; ,Textele au fost interesante şi întrebările relativ uşoare”; ,Exerci iile mi s-au părut uşoare de aceea mi-a plăcut să le rezolv”.

Pentru unii dintre elevi, răspunsul la test a fost perceput ca o provocare şi ca o ocazie de a reflecta la specificul sarcinii şi la strategii de rezolvare; „,Mi-a plăcut să rezolv exerci iile din această unitate din cauză că au fost interesante şi chiar dacă au fost simple, a trebuit să fie gândite cu aten ie”; ,Da, deoarece 
îmi pune mintea la contribu ie şi aflu cât mai multe”; „Deoarece mă ajută să gândesc mult mai bine”; „,Da, pentru că î i pune creierul la treabă”. Din nou, potrivit opiniilor exprimate, motivarea elevilor pentru a rezolva sarcinile s-a datorat şi faptului că au apreciat testul ca fiind prietenos şi atractiv.

De partea opusă, a pu inilor responden i care au declarat că nu le-a plăcut unitatea, merită să fie aduse în discu ie, din aceeaşi perspectivă reflexivă, faptul că ei au dorit să explice (deşi nu li s-a cerut acest lucru în cadrul întrebării) care au fost motivele lor, în ce a constat disconfortul lor, ceea ce îl poate ajuta pe profesor să în eleagă anumite dificultă i ale elevilor referitor la sarcinile de lectură. În acest caz, au fost aduse în discu ie câteva aspecte legate de în elegerea textului (,Nu mi-a plăcut deoarece informa iile nu erau destul de clare”), de lungimea textului (,Nu prea, că a fost cam mult de citit”) sau de modul/solu ia de rezolvare (,Nu prea, deoarece nu eram sigură de răspuns").

Răspunsurile elevilor cu privire la modul în care au perceput dificultatea textului şi interesul suscitat de problematica abordată au pus în eviden ă, în procente mai mari decât cele referitoare la sarcinile de lucru, faptul că textele au fost considerate uşoare şi interesante. Din explica iile oferite de elevi, observăm o valorizare a textelor din perspectiva corelării tematicii cu ideea de cultură generală (,Mi-a plăcut să rezolv aceste exerci ii fiindcă este legat de cultura generală, ajutându-mă să ştiu mai multe") sau a accesului, prin problematica dezvoltată, la informa ii noi (,,In timp ce am citit, am aflat lucruri noi”; ,Da, pentru că am citit mai multe opinii”; , Într-un fel, da, pentru că am avut parte de nişte informa ii care mă pot ajuta").

În aceeaşi ambian $\breve{a}$, deschiderea orizontului personal şi motivarea pentru a afla mai multe sunt valorizate, plecând şi de la diferite op iuni/convingeri personale prealabile: ,Mi-a plăcut să rezolv exerci iile din această unitate, deoarece eu in cu ecologiştii şi fiindcă am inten ii bune pentru oameni, dar şi pentru natură”; ,Da, pentru că am avut parte de nişte informa ii bune care mă pot ajuta pentru dieta zilnică”; ,Mi-au plăcut, deoarece a fost vorba de laptele de vacă şi mie îmi place laptele de vacă, în genere". Într-o notă singulară, remarcăm interesul pentru experien a rezolvării unită ii conectat la contextul evenimentelor generate de pandemie: „Da pentru că îmi era dor să completez ceva pentru şcoală". 
În ceea ce priveşte experien a prealabilă a elevilor (întrebarea 5. Te-ai mai intâlnit la şcoală sau în via ă cotidiană cu texte care sus in puncte de vedere diferite? Dacă da, oferă un exemplu), aproape trei sferturi dintre participan i la studiu afirmă că nu s-au mai întâlnit la şcoală sau în via a cotidiană cu texte care sus in puncte de vedere diferite. În situa ia răspunsurilor afirmative, elevii au spus că ar fi mai avut astfel de texte la şcoală, dar nu-şi mai aduc aminte, exact, contextul. Al i participan i şi-au amintit că experien ele acestea s-au derulat în contextul unor discu ii de interes în comunitate, legate de articole care sus in puncte de vedere diferite privind vaccinarea copiilor, subiectul încălzirii globale sau a sănătă ii mediului. Ca experien ă considerată relevantă pentru întrebare de către un elev, cităm: „În clasa a V-a am ales un preşedinte şi un vicepreşedinte, dar ei aveau puncte de vedere diferite deoarece unul voia să facă un lucru, iar celălalt altul".

Strategii de lectură şi în elegere a textelor părtinitoare. Elevii au fost ruga i să explice cum recunosc că un text este părtinitor (întrebarea 6). Toate aceste strategii de identificare a textului părtinitor la care elevii afirmă că recurg pot fi corelate cu rezultatele itemului 7 al unită ii, din care rezultă faptul că majoritatea elevilor care răspund la această întrebare sus in că sunt de acord cu Sam (,Cu cine eşti de acord? Marchează varianta pe care o consideri adecvată: Chris/Ana/Sam. Formulează o explica ie pentru răspunsul ales. Raportează-te la informa ia din cel pu in unul dintre textele citite").

Contextul itemului din unitatea „Laptele de vacă” este următorul:

„Ana, Chris şi Sam discută despre cele două texte.

Chris: Nu mă interesează ce face proprietarul cafenelei. O să continui să beau lapte zilnic. E un aliment benefic.

Ana: Eu, nu! O să beau mai pu in lapte de acum încolo. Cred că nu e benefic.

Sam: Ştiu şi eu? Cred că trebuie să aflăm mai multe înainte de a trage o concluzie" (OECD, 2019b).

Una dintre strategiile de identificare a textelor părtinitoare aduse în discu ie de către responden i se axează, în general, pe lectura textului şi pe analiza de con inut: „prin informa iile pe care le dă”; ,Îl citesc cu aten ie, apoi 
analizez”; „După con inutul luii”; „Din faptele care se exprimă în text”; „Le citesc cu grijă şi scot informa ii din el”.

Unii responden i consideră că se pot orienta în identificarea unui text părtinitor plecând de la experien e prealabile referitoare la diverse teme care au suscitat controverse (abordări contradictorii) în spa iul/percep ia public(ă). În acest context, elevii afirmă că pot recunoaşte un text părtinitor după titlu, dacă focalizează aten ia pe un subiect sau o persoană (,Când se referă la ceva/ cineva”; ,Se axează asupra unei teme”) sau dacă selectează teme de interes pentru persoană/comunitate, aflate în aten ia publică, teme pe care acesta le percepe ca fiind controversate sau manipulative (,,Dacă arată nişte informa ii importante pe viitor, pentru via a de zi cu zi”; ,,Se vorbeşte mult de sănătatea omului').

O altă modalitate de identificare a textului părtinitor adusă în discu ie de unii dintre elevii participan i la studiu se focalizează pe observarea structurii textului şi a strategiilor argumentative desfăşurate. Experien ele acestora de lectură schi ează o tipologie de situa ii în care, la nivelul textului, se observă un dezechilibru de abordare (,Când o opinie e favorizată mai mult decât alta”; „Când observi că favorizează ceva anume”; ,Aduce argumente fără documentare ştiin ifică”; ,Atunci când cineva aduce argumente pozitive acelui text”). În acest context, merită amintite, ca psihologie inversă, câteva opinii exprimate de elevi cu privire la raportarea lor la textul părtinitor, dintre care amintim aspecte structurale, precum: ,Prin faptul că îmi explică toate punctele de vedere”; „Când se bazează să alegi propriile tale păreri”; „,̂ll recunosc prin faptul că este un articol bazat pe studii”/ „Deoarece arată nişte studii care te pot ajuta” sau „Mă lasă să îmi aleg propriile alegeri”.

$\mathrm{Nu}$ în ultimul rând, elevii amintesc strategii de identificare/în elegere a inten iilor persuasive dezvoltate de un text care presupun căutarea de dovezi/ ancore în afara textului, prin documentare suplimentară şi căutarea de confirmări şi din alte surse (,,̂ncerc să aflu dacă mai există texte care sus in textul precedent, caut mai multe dovezi”; „Căutând mai multe opinii, informându-te şi din alte surse").

Atitudini/obiceiuri de lectură. Elevii au fost întreba i dacă le place să citească şi ce anume le place (întrebările 7 şi 8 din chestionar). Mai mult de 
trei sferturi dintre elevii participan i la studiu au declarat că le place să citească. În timp ce unii dintre aceştia afirmă că interesul lor merge, generic, către lectura de fic iune, a romanelor, de orice fel, sau că nu au vreo preferin ă anume („,Orice fel de căr i”; „Îmi place cam orice”; „Nu am o preferin ă”), cea mai mare parte a responden ilor se declară interesa i de literatură, preferând să citească căr i de dragoste, aventură, poli iste, de mistere, SF, fantasy (Harry Potter). De asemenea, sub influen a culturii cinematografice, unii elevi aduc în discu ie drama sau comedia sau, explicit, căr i care au devenit subiect de film sau de serial. Tot în contextul fic iunii, pe lângă romane, unii dintre elevi preferă să citească basme. Unii dintre elevi se arată interesa i şi de banda desenată (manga).

Căr ile sau articolele cu rol de lectură de informare şi de documentare („Lucruri despre via ă, întâmplări, experien e”; ,Căr i care con in capitole cu titluri diferite") se situează, în preferin ele unora dintre elevi, în domeniul istoriei („În general, îmi plac căr ile de istorie”), dar şi în domeniul naturii sau al dezvoltării personale.

În ceea ce priveşte motiva iile de lectură, unii elevi au adus în discu ie beneficiul formativ, al deschiderii propriului orizont (,Îmi place pentru că totul este interesant şi învă lucruri noi”; „Îmi place să citesc documentare despre diferi i oameni şi să le văd părerea") sau un aspect al receptării unei opere de artă (,Pentru că îmi imaginez lucrurile spuse din o anumită carte”). Dacă unii dintre responden i pun în valoare faptul că citesc mult şi au o diversitate de interese (,Îmi place să citesc chiar foarte mult. Recent, vara asta am citit 5 căr i. Trei dintre ele erau din seria „Fluturi” de Irina Binder, o carte de dezvoltare personală şi o autobiobrafie a unui tenisman. Citesc mai mult căr i de dezvoltare personală, uneori romantice, de dragoste. Cele de SF nu mă prea dau pe spate, ba chiar mă plictisesc uneori”), al ii ar selecta, mai curând, o variantă alternativă, cum ar fi o ecranizare (,Personal, nu prea îmi place să citesc. Prefer să văd un filmule bazat pe ac iunile unui text, decât să îl citesc pentru că ai parte de mai multă ac iune şi în elegi mult mai uşor”), sau ar prefera selec ii făcute de profesori (,Îmi place când profesorii mă pun să citesc diferite fragmente"). 


\section{Concluzii: pledoarie pentru înnoirea practicilor de lectură}

Analiza noastră ne conduce spre următoarele constatări:

- Pe baza răspunsurilor oferite la întrebările din unitatea „Laptele de vacă”, elevii din lotul participant la cercetare identifică cu dificultate informa iile părtinitoare. Din perspectiva opiniilor exprimate în fişa de autoevaluare, observăm abordarea naivă a conceptului de text părtinitor. Prin urmare, considerăm oportun un demers didactic care să vizeze, pe de o parte, procesul de lectură privind rezolvarea de conflicte (dincolo de analiza textului literar canonic sau de preluarea comentariilor asupra literaturii canonice!) şi, pe de altă parte, operarea cu textul informativ multiplu, care sus ine, prin varietatea surselor, puncte de vedere diferite asupra aceleiaşi problematici. Totodată, în privin a alegerii unei astfel de problematici, este utilă considerarea subiectelor de actualitate (de exemplu, pandemia, vaccinarea, explorarea planetei Marte etc.) sau de mare interes pentru grupul de elevi (personalită i din sport, muzică, film etc.). În acest mod, lectura şcolară pregăteşte în mod adecvat pentru via ă.

- Adecvarea răspunsurilor oferite la unitatea aplicată confirmă trendul de lectură din România relevat de PISA. De la începerea participării la studiu, în 2006, elevii noştri au ob inut rezultate mediocre la lectură. Trendul a fost uşor ascendent, urmat de un platou în perioada 2012-2015, pentru ca în 2018 să aibă o uşoară descreştere (OECD, 2018). În condi iile în care curriculumul de limba şi literatură română este compatibil cu Cadrul de referin ă PISA, rezultatele României, situate sub acelea ale statelor din regiune (cu care împăr im o istorie similară şi condi ii socio-economice asemănătoare), ne fac să căutăm solu ia în renovarea practicilor didactice. Analiza noastră a indicat, ca posibile explica ii, situa ii în care rutina didactică poate antrena elevul pe piste de interpretare neadecvate.

- Elevii de la liceul tehnologic declară că citesc. Interesul lor pentru lectură poate fi cultivat şi exploatat prin sarcini interesante (respectiv, nonrutiniere, în afara canonului, fără accentuarea metatextului), care să conducă tânărul cititor pe itinerarii de cunoaştere consonante cu defini ia avansată de PISA (aceea a unei lecturi active, care implică lărgirea orizontului cognitiv).

- Nu în ultimul rând, şcoala digitală experimentată de noi to i din cauza 
pandemiei promovează, mai mult ca oricând, lectura pe ecran. Unitatea aplicată în cercetarea noastră apar ine noilor texte, cu aplicare pe calculator. Acestea fac mai uşoară navigarea de la un text la altul, suprapunerea ecranelor, lectura nonliniară, abordarea multi-coduri de simbolizare, preferată de „Homo Zappiens” (Veen \& Vrakking, 2011). În aceste condi ii, noul format PISA (aplicat în format digital, format la care România va participa şi ea începând din 2021) invită la inovarea practicilor de lectură prin schimbarea accentului de la lectura paginii de carte la lectura ecranelor, prin specularea facilită ilor de navigare. Nu facem o pledoarie pentru o lectură digitală de dragul PISA, ci pentru a sprijini o lectură de profunzime în contextul digitalizării, pentru a limita efectul de superficialitate eviden iat de N. Carr (2012). Aceasta se poate face în mod sistematic în şcoală, ca o componentă fundamentală a dezvoltării competen ei de litera ie şi a celei personale, sociale şi de a învă a să înve i.

Orientarea spre o lectură cu scop, relevantă pentru subiectul cititor, care săi mobilizeze interesele şi să-i extindă orizontul de cunoaştere depinde de şcoală. Nu se va realiza automat şi nici din întâmplare, prin utilizarea extensivă a noilor media de către elevi, ci prin efortul sus inut al echipei de profesori din fiecare şcoală.

\section{Mul umiri}

Autorii mul umesc echipei PISA 2018 pentru efortul de administrare şi de construire a bazei de date na ionale.

Mul umiri, totodată, doamnelor profesoare Maria Rediu şi Mirella Popescu, care ne-au ajutat la aplicarea unită ii la clasa a IX-a, şi lui Luca Mihăilescu, pentru prelucrarea statistică a datelor.

\section{Referin e}

- Carr, N. (2012). Superficialii. Efectele internetului asupra creierului uman. Editura Publica. 
- OECD (2018). PISA 2018 Database. https://www.oecd.org/pisa/data/2018database/

- OECD (2019a). PISA 2018 - Assessment and Analytical Framework. https://www.oecd-ilibrary.org/education/pisa-2018-assessment-and-analyticalframework_b25efab8-en

- OECD (2019b). 2018 - PISA Competen a de lectură. Itemi publici. http://www.ise.ro/wp-content/uploads/2020/07/PISA_itemi_publici-lectura.pdf

- Sarivan, L., Novak, C., Mihăilescu, A., \& Pleşa, C. (2020). Meaning in Reading. Could Romania's PISA 2018 Results Become a Wake-Up Call to Innovate Practices? In Innovation in Language Learning. Conference Proceedings, Filodiritto Editore, Bologna, pp. 244-250.

https://conference.pixel-online.net/ICT4LL/files/ict4l1/ed0013/Conference\%20 Proceedings.pdf

- Veen, W., \& Vrakking, B. (2011). Homo Zappiens. Joc şi învă are în epoca digitală. Editura Sigma.

The online version of this article can be found at: http://revped.ise.ro/category/2020-en/

\section{(cc) EY-NC- $\mathrm{BA}$}

This work is licensed under the Creative Commons Attribution-NonCommercial-ShareAlike 4.0 International License.

To view a copy of this license, visit http://creativecommons.org/licenses/by-nc-sa/4.0/ or send a letter to Creative Commons, PO Box 1866, Mountain View, CA 94042, USA.
Versiunea online a acestui articol poate fi găsită la: http://revped.ise.ro/category/2020-ro/

\section{$(\mathrm{Cc}) \overline{\mathrm{B}-\mathrm{NC}-\mathrm{SA}}$}

Această lucrare este licen iată sub Creative Commons Attribution-NonCommercial-ShareAlike 4.0 International License.

Pentru a vedea o copie a acestei licen e, vizita $i$ http://creativecommons.org/licenses/by-nc-sa/4.0/ sau trimite i o scrisoare către Creative Commons, PO Box 1866, Mountain View, CA 94042, SUA. 